\title{
PERBANDINGAN NILAI AGREGASI TROMBOSIT PADA PASIEN DIABETES MELLITUS TIPE 2 DENGAN DISLIPIDEMIA DAN NORMOLIPIDEMIA DI RSUP PROF. DR. R. D. KANDOU MANADO
}

\author{
${ }^{1}$ Ivan Chandra Sulamanda \\ ${ }^{2}$ George Arthur Mantiri \\ ${ }^{2}$ Maya Fane Memah
}

\author{
${ }^{1}$ Kandidat Skripsi Fakultas Kedokteran Universitas Sam Ratulangi Manado \\ ${ }^{2}$ Bagian Patologi Klinik Fakultas Kedokteran Universitas Sam Ratulangi Manado \\ Email: ivansulamanda10_113@yahoo.com
}

\begin{abstract}
Insulin resistance occurs in patients with type 2 diabetes mellitus, which stimulates lipolysis in adipose tissue resulting in increasing of free fatty acid and dyslipidemia. Dyslipidemia is associated with platelet reactivity and thrombogenic potency. Examination of platelet aggregation aims to detect abnormalities of platelet function. This study aimed to see comparison of platelet aggregation value in patients with type 2 diabetes with dyslipidemia and with patients who have normal blood lipid level. The Methods of this study used an observational analytic, using comparative hypothesis testing. This study were conducted on 30 diabetes mellitus patients, in which 15 of them have dyslipidemia and the other 15 has normal lipid level. These patients were registered at Poliklinik Endokrin Metabolik RSUP Prof. Dr. R. D. Kandou Manado. Blood samples of patients were processed in Laboratorium Prokita Malalayang Manado. The Results of this research was $T$ test showed that there are significant differences of the platelet aggregation value with ADP $10 \mu \mathrm{m}$ agonist between patients with type 2 diabetes with dyslipidemia and with patients who have normal blood lipid level ( $\mathrm{p}=0.019)$. MannWhitney test showed that there are significant differences of the platelet aggregation value with ADP 5 $\mu \mathrm{m}$ agonist between patients with type 2 diabetes with dyslipidemia and with patients who have normal blood lipid level $(\mathrm{p}=0.006)$. Most patients studied in this study are at an older age $(86.7 \%)$, with an equal number of men and women. Conclusion: There are significant differences of the platelet aggregation value between patients with type 2 diabetes with dyslipidemia and with patients who have normal blood lipid level, whether using ADP $10 \mu \mathrm{m}$ agonist or ADP $5 \mu \mathrm{m}$ agonist.
\end{abstract}

Keywords: Platelet aggregation, type 2 diabetes mellitus, dyslipidemia

\begin{abstract}
Abstrak: Pada pasien diabetes mellitus tipe 2 terjadi resistensi insulin sehingga merangsang lipolisis di jaringan adiposa yang meningkatkan asam lemak bebas dan menimbulkan dislipidemia. Dislipidemia sering dikaitkan dengan peningkatan aktivitas platelet dan potensi trombogenik. Pemeriksaan agregasi trombosit bertujuan untuk mendeteksi abnormalitas fungsi trombosit. Penelitian ini bertujuan untuk melihat perbandingan nilai agregasi trombosit pada pasien diabetes mellitus tipe 2 dengan dislipidemia dan normolipidemia. Metode penelitian ini menggunakan observasional analitik dengan menggunakan metode uji hipotesis komparatif. Subjek dalam penelitian ini berjumlah 30 orang, 15 orang pasien diabetes mellitus tipe 2 dengan dislipidemia dan 15 orang pasien diabetes mellitus tipe 2 dengan normolipidemia yang terdaftar di Poliklinik Endokrin Metabolik RSUP Prof. Dr. R. D. Kandou Manado. Pemeriksaan sampel darah pasien dilakukan di Laboratorium Prokita Malalayang Manado. Hasil pada penelitian ini adalah uji T menunjukkan bahwa terdapat perbedaan yang signifikan antara nilai agregasi trombosit dengan agonist ADP $10 \mu \mathrm{m}$ pada pasien diabetes mellitus tipe 2 dengan dislipidemia dan normolipidemia $(\mathrm{p}=0,019)$. Uji Mann-Whitney menunjukkan bahwa juga terdapat perbedaan yang signifikan antara nilai agregasi trombosit dengan agonist ADP 5 $\mu \mathrm{m}$ pada pasien diabetes mellitus tipe 2 dengan dislipidemia dan normolipidemia $(\mathrm{p}=0,006)$. Karakteristik terbanyak pada pasien diabetes mellitus tipe 2 terdapat pada usia tua (86,7\%) dengan
\end{abstract}


jenis kelamin baik laki - laki maupun perempuan sama banyak (50\%).

Kesimpulan: Terdapat perbedaan signifikan antara nilai agregasi trombosit pada pasien diabetes mellitus tipe 2 dengan dislipidemia dan normolipidemia baik menggunakan agonist ADP $10 \mu \mathrm{m}$ maupun ADP $5 \mu \mathrm{m}$.

Kata Kunci: Agregasi trombosit, diabetes mellitus tipe 2, dislipidemia

Diabetes mellitus merupakan penyakit kronis yang disebabkan oleh warisan atau diperoleh dari kekurangan produksi insulin oleh pankreas, atau dengan tidak efektifnya insulin yang diproduksi, oleh karena itu terjadi peningkatan konsentrasi glukosa dalam darah, yang pada akhirnya merusak banyak sistem tubuh, khususnya pembuluh darah dan saraf. $^{1}$

Pada abad ke-21 ini diabetes mellitus merupakan salah satu masalah kesehatan yang besar dan terus berkembang. ${ }^{2}$ Pada tahun 2011 terdapat 366 juta jiwa yang menderita penyakit diabetes mellitus dan diperkirakan akan terus meningkat mencapai 552 juta jiwa pada tahun 2030. ${ }^{3}$ Di tahun 2012 lebih dari 371 juta jiwa yang menderita penyakit diabetes mellitus, jumlah orang yang menderita penyakit ini terus meningkat di berbagai negara, setengah dari penderita penyakit ini tidak terdiagnosa, 4,8 juta jiwa yang mengidap penyakit diabetes mellitus ini meninggal, dan lebih dari 471 milyar dollar Amerika dihabiskan untuk menangani penyakit diabetes mellitus ini. ${ }^{4}$

Indonesia kini telah menduduki rangking keempat jumlah penyandang diabetes terbanyak setelah Amerika Serikat, China dan India. Berdasarkan data dari Badan Pusat Statistik (BPS) jumlah penyandang diabetes pada tahun 2003 sebanyak 13,7 juta orang dan berdasarkan pola pertambahan penduduk diperkirakan pada 2030 akan ada 20,1 juta penyandang diabetes, Wealth Health Organization (WHO) memprediksi kenaikan jumlah penyandang diabetes mellitus di Indonesia dari 8,4 juta pada tahun 2000 menjadi sekitar 21,3 juta pada tahun $2030 .^{5}$

Pada pasien diabetes mellitus tipe 2 terjadi abnormalitas trombosit yaitu peningkatan agregasi dan adhesi dari trombosit. ${ }^{6}$ Peningkatan agregasi trombosit yang direspon dengan adenosine diphospate (ADP), thrombin, kolagen, asam arakidonat, dan epinephrine terlihat pada pasien diabetes mellitus dibandingkan dengan orang yang tidak menderita diabetes mellitus. Pada kondisi in vitro trombosit ini distimulasi dengan agonist trombosit dan menunjukkan penurunan ambang batas tahanan untuk trombosit beragregasi.

Beberapa mekanisme yang diduga berperan dalam peningkatan reaktivitas trombosit antara lain disebabkan oleh kelainan metabolisme dan selular yaitu hiperglikemi, resistensi insulin, dan kondisikondisi metabolik yang berkaitan dengan penyakit diabetes mellitus seperti obesitas, dislipidemia, dan peningkatan inflamasi, serta kelainan-kelainan selular lainnya. Disfungsi endotel, hiperaktivitas trombosit, gangguan keseimbangan fibrinolitik, keabnormalan aliran darah memungkinkan peningkatan aterosklerosis dan resiko kejadian trombosis vaskular. Pasien dengan diabetes mellitus terjadi perubahan dalam distribusi lipid sehingga meningkatkan resiko aterosklerosis. Keadaan ini ditandai dengan trigliserida plasma yang tinggi, kolestrol high density lipoprotein (HDL) yang rendah, dan meningkatnya kolestrol low density lipoprotein (LDL). 6,8,9

Disregulasi transportasi dan metabolisme kolestrol merupakan faktor resiko penting untuk terjadinya aterosklerosis dan keterkaitan dengan meningkatnya reaktivitas dari trombosit, namun mekanisme molekular yang menghubungkan hiperkolesterolemia dengan peningkatan fungsi trombosit masih diteliti lebih lanjut. ${ }^{10}$

\section{METODE PENELITIAN}

Penelitian ini bersifat observasional analitik dengan menggunakan metode uji hipotesis komparatif dan dilaksanakan di 
Poliklinik Endokrin - Metabolik bagian Penyakit Dalam RSUP Prof. Dr. R. D. Kandou Manado. Pemeriksaan agregasi trombosit dilakukan di Laboratorium Prokita Manado. Waktu penelitian dilakukan pada bulan November 2013 sampai Februari 2014. Sampel penelitian ini yaitu 15 individu yang menderita diabetes mellitus tipe 2 dengan dislipidemia dan 15 individu yang menderita diabetes mellitus tipe 2 dengan normolipidemia yang termasuk kriteria inklusi.

\section{HASIL PENELITIAN}

Subjek pada penelitian ini berjumlah 30 orang. Karakteristik subjek penelitian berdasarkan umur dan jenis kelamin dapat dilihat pada Tabel 1, dimana jumlah pasien diabetes mellitus tipe 2 dengan dislipidemia yaitu sebanyak 15 orang (50\%) dan pasien diabetes mellitus tipe 2 dengan normolipidemia yaitu sebanyak 15 orang (50\%).

Umur yang termasuk dalam kriteria inklusi ialah 40 hingga 80 tahun. Penelitian ini ditemukan lebih banyak subjek yang berusia tua yaitu sebanyak 26 orang (86,7\%), sedangkan subjek berusia dewasa berjumlah 4 orang (13,3\%). Jenis kelamin pada penelitian ini baik laki-laki dan perempuan memiliki distribusi yang sama yaitu masing-masing sebanyak 15 orang (50\%).

\section{Data nilai agregasi trombosit pada pasien diabetes mellitus tipe 2 dengan dislipidemia}

Data nilai agregasi trombosit pada pasien diabetes mellitus tipe 2 dengan dislipidemia dapat dilihat pada Tabel 2 . hasil penelitian ini ditemukan nilai agregasi trombosit pada pasien diabetes mellitus tipe 2 dengan dislipidemia dengan menggunakan ADP $10 \mu \mathrm{m}$ terendah yaitu $28 \%$ dan tertinggi yaitu $67 \%$, sehingga diperoleh nilai rata-rata sebesar $48,07 \%$ yang dapat dibulatkan menjadi 48\% dengan simpang baku 10,78\%. Pada nilai agregasi trombosit dengan menggunakan ADP $5 \mu \mathrm{m}$ terendah yaitu $30 \%$ dan tertinggi yaitu $106 \%$, sehingga diperoleh nilai rata-rata sebesar $56,27 \%$ yang dapat dibulatkan menjadi 56\% dengan simpang baku 24,99\%.

\section{Data nilai agregasi trombosit pada pasien diabetes mellitus tipe 2 dengan normolipidemia}

Data nilai agregasi trombosit pada pasien diabetes mellitus tipe 2 dengan normolipidemia dapat dilihat pada Tabel 3. Hasil penelitian ini ditemukan nilai agregasi trombosit dengan menggunakan ADP $10 \mu \mathrm{m}$ terendah yaitu $16 \%$ dan tertinggi yaitu $68 \%$, sehingga diperoleh nilai rata - rata sebesar $35,60 \%$ yang dapat dibulatkan menjadi 36\% dengan simpang baku 13,85\%. Pada nilai agregasi trombosit dengan menggunakan ADP $5 \mu \mathrm{m}$ terendah yaitu 9\% dan tertinggi yaitu 66\%, sehingga diperoleh nilai rata-rata sebesar 32,20\% yang dapat dibulatkan menjadi 32\% dengan simpang baku 17,45\%.

\section{Analisis perbandingan nilai agregasi trombosit pada pasien diabetes mellitus tipe 2 dengan dislipidemia dan normolipidemia}

Perbandingan nilai agregasi trombosit pada pasien diabetes mellitus tipe 2 dengan dislipidemia dan normolipidemia dapat dilihat pada Tabel 4 dan 5. Uji normalitas data didapatkan distribusi normal pada ADP $10 \mu \mathrm{m}$ dan tidak normal pada ADP $5 \mu \mathrm{m}$. Analisis uji $\mathrm{T}$ dua variabel pada pasien diabetes mellitus tipe 2 dengan dislipidemia dan normolipidemia dengan menggunakan ADP $10 \mu \mathrm{m}$, menunjukkan nilai signifikansi $P<0,05$ yaitu 0,019. Analisis uji MannWhitney dua variabel pada pasien diabetes mellitus tipe 2 dengan dislipidemia dan normolipidemia dengan menggunakan ADP $5 \mu \mathrm{m}$, menunjukkan nilai signifikansi $P<$ 0,05 yaitu 0,006 . 
Tabel 1. Karakteristik subjek penelitian berdasarkan umur dan jenis kelamin

\begin{tabular}{cccc}
\hline Karakteristik & Klasifikasi & Frekuensi & Persentasi \\
\hline \multirow{2}{*}{ Umur } & Dewasa ( $\leq 49$ Tahun) & 4 & $13,3 \%$ \\
& Tua ( $\geq 50$ Tahun) & 26 & $86,7 \%$ \\
\multirow{2}{*}{ Jenis Kelamin } & Laki - laki & 15 & $50 \%$ \\
& Perempuan & 15 & $50 \%$ \\
\hline
\end{tabular}

Tabel 2. Data nilai agregasi trombosit pada pasien diabetes mellitus tipe 2 dengan dislipidemia

\begin{tabular}{ccccc}
\hline Variabel & $\begin{array}{c}\text { Nilai } \\
\text { Terendah }\end{array}$ & $\begin{array}{c}\text { Nilai } \\
\text { Tertinggi }\end{array}$ & $\begin{array}{c}\text { Nilai Rata - } \\
\text { rata }\end{array}$ & $\begin{array}{c}\text { Simpang } \\
\text { Baku }\end{array}$ \\
\hline $\begin{array}{c}\text { Pasien DM tipe 2 dengan dislipidemia } \\
\text { (ADP 10 } \mu \mathrm{m} \text { ) }\end{array}$ & $28 \%$ & $67 \%$ & $48,07 \%$ & $10,78 \%$ \\
$\begin{array}{c}\text { Pasien DM tipe 2 dengan dislipidemia } \\
\text { (ADP 5 } \mu \mathrm{m})\end{array}$ & $30 \%$ & $106 \%$ & $56,27 \%$ & $24,99 \%$ \\
\hline
\end{tabular}

Tabel 3. Data nilai agregasi trombosit pada pasien diabetes mellitus tipe 2 dengan normolipidemia

\begin{tabular}{ccccc}
\hline Variabel & $\begin{array}{c}\text { Nilai } \\
\text { Terendah }\end{array}$ & $\begin{array}{c}\text { Nilai } \\
\text { Tertinggi }\end{array}$ & $\begin{array}{c}\text { Nilai Rata - } \\
\text { rata }\end{array}$ & $\begin{array}{c}\text { Simpang } \\
\text { Baku }\end{array}$ \\
\hline $\begin{array}{c}\text { Pasien DM tipe 2 dengan } \\
\text { normolipidemia (ADP 10 } \mu \mathrm{m}) \\
\begin{array}{c}\text { Pasien DM tipe 2 dengan } \\
\text { normolipidemia (ADP 5 } \mu \mathrm{m})\end{array}\end{array}$ & $16 \%$ & $68 \%$ & $35,60 \%$ & $13,85 \%$ \\
\hline
\end{tabular}

Tabel 4. Perbandingan nilai agregasi trombosit dengan menggunakan ADP $10 \mu \mathrm{m}$ pada pasien diabetes mellitus tipe 2 dengan dislipidemia dan normolipidemia

\begin{tabular}{|c|c|c|}
\hline Variabel & Kategori & Nilai p \\
\hline \multirow{3}{*}{ Nilai Agregasi Trombosit } & DM Tipe 2 dengan dislipidemia (ADP & \multirow{3}{*}{0,019} \\
\hline & $10 \mu \mathrm{m})$ & \\
\hline & $\begin{array}{c}\text { DM Tipe } 2 \text { dengan normolipidemia } \\
\text { (ADP } 10 \mu \mathrm{m})\end{array}$ & \\
\hline
\end{tabular}

Tabel 5. Perbandingan nilai agregasi trombosit dengan menggunakan ADP $5 \mu \mathrm{m}$ pada pasien diabetes mellitus tipe 2 dengan dislipidemia dan normolipidemia

\begin{tabular}{ccc}
\hline Variabel & Kategori & Nilai p \\
\hline \multirow{2}{*}{ Nilai Agregasi Trombosit } & DM Tipe 2 dengan dislipidemia (ADP 5 & \\
& $\mu \mathrm{m})$ & 0,006 \\
& DM Tipe 2 dengan normolipidemia & \\
& $($ ADP $5 \mu \mathrm{m})$ & \\
\hline
\end{tabular}




\section{BAHASAN}

Pada penelitian ini jumlah subjek penelitian yang memenuhi kriteria inklusi ialah 30 orang di Poliklinik Endokrin Metabolik Bagian Penyakit Dalam RSUP. Prof. Dr. R. D. Kandou Manado lalu diambil sampel darahnya dan diperiksa nilai agregasi trombositnya di laboratorium Prokita Malalayang Manado.

Menurut World Health Organization $(\mathrm{WHO})^{1}$ peningkatan prevalensi umur penderita diabetes mellitus tipe 2 di negara berkembang yaitu 45 tahun keatas, bertambahnya usia merupakan salah satu faktor resiko terjadinya penyakit diabetes mellitus tipe 2. Hasil pada penelitian ini menunjukkan jumlah usia tua ( $\geq 50$ tahun) lebih banyak dibandingkan dengan usia dewasa $\leqslant 49$ tahun). Pada penelitian ini jenis kelamin baik laki - laki maupun perempuan memiliki jumlah yang sama banyak yaitu masing - masing berjumlah 15 orang.

Interpretasi nilai normal yang digunakan oleh peneliti menggunakan standar nilai normal yang digunakan oleh laboratorium Prokita Malalayang Manado yaitu nilai ADP $10 \mu \mathrm{m}$ adalah 49\% - 84\% dan nilai ADP $5 \mu \mathrm{m}$ adalah 25\% - 68\%. Pada penelitian ini interpretasi nilai agregasi trombosit pada pasien diabetes mellitus tipe 2 dengan dislipidemia adalah terdapat 4 orang hiperagregasi, 3 orang normoagregasi, dan 8 orang hipoagregasi, dengan nilai agregasi trombosit terendah menggunakan ADP $10 \mu$ m adalah 28\% dan nilai tertinggi adalah $67 \%$, nilai agregasi trombosit terendah menggunakan ADP 5 $\mu \mathrm{m}$ adalah $30 \%$ dan nilai tertinggi adalah $106 \%$.

Pada interpretasi nilai agregasi trombosit pada pasien diabetes mellitus tipe 2 dengan dislipidemia didapatkan 8 orang pasien yang interpretasinya hipoagregasi ini bisa dikarenakan pengaruh obat antidiabetik, menurut Siluk ${ }^{11}$ ada beberapa obat anti diabetik yang mempunyai efek untuk menghambat agregasi trombosit misalnya dari golongan glimepirid, glicazide, glibenclamide, gliquidone, glipolamide, chlorpropamide, glipicide, tolbutamide dan insulin yang dapat meningkatkan proses fibrinolisis.

Interpretasi nilai agregasi trombosit pada pasien diabetes mellitus tipe 2 dengan normolipidemia adalah terdapat 1 orang normoagregasi dan 14 orang hipoagregasi, dengan nilai agregasi trombosit terendah menggunakan ADP $10 \mu \mathrm{m}$ adalah 16\% dan nilai tertinggi adalah 68\%, nilai agregasi trombosit terendah menggunakan ADP $5 \mu \mathrm{m}$ adalah 9\% dan nilai tertinggi adalah 66\%.

Pada perbandingan interpretasi nilai agregasi trombosit pada pasien diabetes mellitus tipe 2 dengan dislipidemia dan normolipidemia didapatkan bahwa terdapat 4 orang pasien yang hasilnya hiperagregasi pada diabetes mellitus tipe 2 dengan dislipidemia sedangkan pada normolipidemia tidak terdapat pasien yang hasilnya hiperagregasi melainkan terdapat 14 orang yang hasilnya hipoagregasi. Perbedaan pada hasil interpretasi ini dapat disebabkan oleh keabnormalan fungsi trombosit pada kadar lipid abnormal yang mengakibatkan peningkatan ekspresi dari molekul - molekul trombosit, peningkatan reseptor permukaan trombosit, ditambah dengan penurunan kadar insulin meningkatkan respon trombosit pada adenosine difosfat (ADP) dan kelainan abnormalitas selular lainnya. ${ }^{6,9,12}$

Nilai rata - rata agregasi trombosit pada pasien diabetes mellitus tipe 2 dengan dislipidemia dan normolipidemia dengan menggunakan ADP $10 \mu \mathrm{m}$ adalah nilai agregasi trombosit pada pasien diabetes mellitus tipe 2 dengan dislipidemia didapatkan lebih tinggi 48,07\% dibandingkan dengan normolipidemia 35,60\%. Dengan menggunakan ADP $5 \mu \mathrm{m}$ nilai agregasi trombosit pada pasien diabetes mellitus tipe 2 dengan dislipidemia juga didapatkan lebih tinggi 56,27\% dibandingkan dengan normolipidemia 32,20\%, yang berarti jika dilihat secara nominal terdapat perbedaan antara kedua variabel.

Pada uji statistik pula nilai agregasi trombosit pada pasien diabetes mellitus tipe 2 dengan dislipidemia dan normolipidemia dengan ADP $10 \mu \mathrm{m}$ menggunakan uji $\mathrm{T}$ 
didapatkan nilai signifikansi $\mathrm{p}<0,05$ yaitu 0,019 dan dengan ADP $5 \mu \mathrm{m}$ menggunakan uji Mann-Whitney didapatkan nilai signifikansi $\mathrm{p}<0,05$ yaitu 0,006. Hasil ini menunjukkan bahwa terdapat perbedaan nilai agregasi trombosit pada pasien diabetes mellitus tipe 2 dengan dislipidemia dan normolipidemia.

Hasil penelitian ini memiliki kesimpulan yang sama dengan penelitian yang dilakukan oleh Ferreiro, dkk ${ }^{12}$ yang menyatakan bahwa diabetes mellitus tipe 2 memainkan peranan penting dalam hiperaktivasi trombosit. Pada akhirnya pasien dengan diabetes mellitus tipe 2 sering mengalami masalah komplikasi makrovaskular dan mikrovaskular seperti aterosklerotik kardiovaskular dan stroke. ${ }^{9,13}$

Hasil penelitian yang sama dengan penelitian-penelitian sebelumnya menunjukkan bahwa terdapat perbedaan nilai agregasi trombosit pada pasien diabetes mellitus tipe 2 dengan dislipidemia dibandingkan pada pasien diabetes mellitus tipe 2 dengan normolipidemia yang dapat dilihat bahwa nilai agregasi trombosit pada diabetes mellitus tipe 2 dengan dislipidemia lebih tinggi dibandingkan dengan nilai agregasi trombosit pada pasien diabetes mellitus tipe 2 dengan normolipidemia.

Pada penelitian ini juga masih terdapat banyak keterbatasan penelitian seperti: terbatasnya jumlah sampel, penggunaan berbagai macam jenis obat diabetes mellitus tipe 2 yang dipakai pasien subjek penelitian, kadar agonist ADP yang digunakan $5 \mu \mathrm{m}$ dan $10 \mu \mathrm{m}$, dan waktu penelitian yang singkat untuk pengumpulan sampel dan pembuatan sampel.

\section{SIMPULAN}

Berdasarkan hasil penelitian ini maka dapat disimpulkan bahwa: Terdapat perbedaan bermakna antara nilai agregasi trombosit pada pasien diabetes mellitus tipe 2 dengan dislipidemia dan normolipidemia dengan menggunakan agonist ADP $10 \mu \mathrm{m}$ maupun menggunakan agonist ADP $5 \mu \mathrm{m}$. Nilai rata - rata agregasi trombosit pada pasien diabetes mellitus tipe 2 dengan dislipidemia dan normolipidemia yang mana pada pasien diabetes mellitus tipe 2 dengan dislipidemia lebih tinggi dibandingkan dengan pasien diabetes mellitus tipe 2 dengan normolipidemia. Karakteristik terbanyak pada pasien diabetes mellitus tipe 2 ditemukan pada usia tua ( $\geq 50$ tahun).

\section{SARAN}

Berdasarkan hasil penelitian dan pembahasan, maka penulis menyarankan beberapa hal, yaitu: Meningkatkan jumlah sampel penelitian untuk menghindari terjadinya bias dalam penelitian. Menggunakan agonist ADP dengan kadar agonist 1, 2, 5, dan $10 \mu \mathrm{m}$ agar ketelitian interpretasi nilai agregasi trombosit lebih efektif. Penelitian ini dapat dilakukan pada penyakit - penyakit yang berhubungan dengan gangguan vaskular seperti pada penyakit jantung koroner dan stroke. Perlunya dilakukan penelitian lebih lanjut terhadap hubungan antara fungsi agregasi trombosit pada penyakit diabetes mellitus tipe 2 dengan dislipidemia.

\section{DAFTAR PUSTAKA}

1. World Health Organization. Diabetes Mellitus. $2013 . \quad$ Tersedia: http://www.who.int/mediacentre/factsheets/fs 138/en/.

2. International Diabetes Federation. Global diabetes plan 2011-2021. 2011. Tersedia : http://www.idf.orf/sites/default/files/GlobalD iabetes_Plan_Final.pdf.

3. International Diabetes Federation. IDF Diabetes Atlas Foreword. 2011. Tersedia: http://www.idf.org/diabetesatlas/5e/foreword

4. International Diabetes Federation. IDF Diabetes Atlas Update 2012. 2012.

Tersedia: http://www.idf.org/diabetesatlas/5e/Update2 012.

5. Pusat data dan Informasi PERSI. RI Rangking Keempat Jumlah Penderita 
Diabetes Tebanyak Dunia. 2011. Tersedia:

http://www.pdpersi.co.id/content/news.ph $\mathrm{p}$ ?mid=5\&nid=618\& catid=23.

6. Huri HZ. Dyslipidemia and type 2 diabetes mellitus : implication and role of antiplatelet agents in primary prevention of cardiovascular disease. 2012. Tersedia:http://cdn.intechopen.com/pdfs/2 7493/InTech-

Dyslipidemia_and_type_2_diabetes_melli tus_implications_and_role_of_antiplatelet _agents_in_primary_prevention_of_cardi ovascular_disease.pdf.

7. Saboor M, Moinuddin, Ilyas S. : Platelets structural, functional, and metabolic alterations in diabetes mellitus. 2012. Tersedia: http://www.pps.org.pk/PJP/82/Saboor.pdf.

8. Kodiatte TA, Manikyam UK, Rao SB, Jagadish TM, Redde M, Lingaiah HK, dkk. Mean platelet volume in type 2 diabetes mellitus. J Lab Physicians. 2012;4:5-9.

9. Stratmann B, Tschoepe D. Pathobiology and cell interactions of platelets in diabetes. Diabetes and Vascular Research. 2005;2:1623.

10. Kaplan ZS, Jackson SP. : SR-BI and fatty platelets. $2010 . \quad$ Tersedia: http://bloodjournal.hematologylibrary.org/co ntent/116/11/1827.full.

11. Prima A. Perbedaan Pola Gangguan Hemostasis Antara Penyakit Ginjal Kronik Prehemodialisis Dengan Diabetes Mellitus dan Non Diabetes Mellitus (Thesis). Semarang: Fakultas Kedokteran Universitas Diponegoro; 2008.

12. Ferreiro JS, Gomez JA, Angiolillo D. Platelet abnormalities in diabetes mellitus. Diabetes and Vascular Research. 2010;7:251-59.

13. Vinik AI, Erbas T, Park TS, Nolan R, Pittenger GL. Platelet dysfunction in type 2 diabetes. Diabetes Care. 2001;24:1476-85. 